ISMC 2021

$16^{\text {th }}$ International Strategic Management Conference

\title{
APPLICATION OF SELECTED CREATIVE ACCOUNTING TECHNIQUES TO DETECT FRAUD IN FINANCIAL STATEMENTS
}

\author{
Monika Poradova (a)*, Lucia Michlakova (b) \\ *Corresponding author \\ (a) University of Zilina, Faculty of Operation and Economics of Transport and Communications, Univerzitna 8215/1, \\ 010 26, Zilina, Slovak Republic, monika.poradova@fpedas.uniza.sk \\ (b) University of Zilina, Faculty of Operation and Economics of Transport and Communications, Univerzitna 8215/1, \\ 010 26, Zilina, Slovak Republic, lucia.michalkova@fpedas.uniza.sk
}

\begin{abstract}
In a modern globalised and liberalised era, businesses face stiff competition and are therefore under constant pressure. In such an environment, businesses typically use creative accounting practices. The aim of the present article is to analyse the possibilities of using the chosen technique and method of manipulation by profit on the selected company. The company analysed in the presented article is a company that "optimized" its financial statements for tax purposes in 2018. The article submitted shall consist of four parts. The first part deals with the issue of creative accounting in general, but also in the Slovak Republic. The second part deals with the methods that have been used within the framework of the article. In the present paper we will look at two models: the Beniesh model and the Kanapickiene Grundiene model. The third part of the article is devoted to the analysis of the possibility of using the chosen technique and method of manipulation of profits on the selected company in the conditions of the Slovak Republic. Part three of the article also includes a discussion on the subject. The fourth part of the article deals with the conclusions drawn from the research. The descriptive method, analysis, mathematical methods, comparison and synthesis were used in the processing of the submitted paper creation.
\end{abstract}

2357-1330 @ 2021 Published by European Publisher.

Keywords: Beneish model, creative accounting, financial statements, fraud, Kanapickiene - Grundiene model 


\section{Introduction}

Outputs from the accounting process (financial statements) are the means for internal and external stakeholders who can obtain information about the financial performance of the company. Many of the important decisions made by these stakeholders are based on the financial deadline stated in the financial statements. Therefore, their accuracy and reliability are crucial for companies. Mainly because they can make or make appropriate decisions. In order to produce transparent, timely and reliable financial statements, the accounting process should be governed by objective and consistent rules.

Creative accounting represents the process of manipulating accounting data in order to transform financial statements from the form they should have to the form their creators would like (Stangova \& Vighova, 2016) The history of creative accounting dates back to the period when the pillars of doubleentry bookkeeping were officially built. This is the period of the late Middle Ages. Worldwide, the general concept of creative accounting has become important mainly with dishonest practices and fraud in economic practice (Salaga et al., 2015) The direct definition sounds like the process of disposing of accounting data in order to transform financial accounting statements from what they would look like when those responsible would want them to be true and true. In creative accounting, it is often very difficult to determine whether a given method of creative accounting is good or bad, whether the rules are broken or not. It depends on the basic purpose of using the creative accounting for which it is used and on the way in which it is used.

The classic elements of creative accounting are originality, individuality, unconventionality, uniqueness, peculiarity, individuality, risk, etc. Creative accounting is a practice in which a company uses gaps to prove that they are more advantageous or financially stable than they actually are. However, in many cases of creative accounting, the company violates the law. Most likely, he engages in unethical behaviour. This can lead to suspicion of government audits and, in the event of fraud, to the closure of the business (Howard et al., 2020; Siekelova et al., 2015)

Creative accounting in the conditions of the legislation of the Slovak Republic is a very specific topic. It is this topic that is very little perceived in the Slovak Republic in the field of ethics because none of the laws directly defines it. Despite insufficient attention to the issue of creative accounting, global surveys provide us with information on significant business losses in identifying problems. Deciding in situations where the steps to reveal creative accounting cannot be precisely determined by it helps to identify a code of ethics for certified accountants who specialize directly in the field (Pieters, 2019).

Manipulation of accounting documents is a criminal offence in the conditions of the Slovak Republic in the given circumstances. The National Council of the Slovak Republic issued the Criminal Code no. 300/2005 Coll. of 20 May 2005. This law regulates the bases of criminal liability, types of penalties, types of protective measures for their imposition and the facts of criminal offences. Article 259 (1) of that law states that creative accounting is the intentional distortion of economic and commercial records. It further defines it as false or grossly distorting data in statements, in reports, in input data entered into the computer. Other main laws and standards related to the performance of statutory audit in the Slovak Republic include Act no. 423/2005 Coll. on statutory audit. The said law also deals with the examination of financial statements (Savova, 2021). 
Fraud usually starts to a lesser extent. In general, we can divide fraud into two categories: external and internal. External fraud, where an entity becomes rich at the expense of another company without the help of its employees. An example is an agreement with a supplier, to whom we will provide a deposit for future performance, but this performance will never occur. Internal fraud is inherently much more difficult to identify (Wells, 2014).

There is sometimes only a very thin line between creative (under current legislation) and fraudulent reporting. Fraudulent reporting options can be exploited in several types of transactions. Transactions in which the principle of fair and fair presentation of the facts may be seriously violated include: accruals, notional sales and adverse liabilities or costs.

Accruals, when the value of the main data of financial statements can be influenced by the method of incorrect recording of accounting operations (Vagner et al., 2021). For example, the company is able to increase its reported turnover in such a way that, at the end of the period, it invoices deliveries resulting from contracts, which are not to take place until the following financial year. Fictitious revenues and incorrect valuation of company assets are one of the ways of reporting fictitious revenues can be the creation of false invoices for fictitious or even real company customers.

Another case may arise in the case of the recognition of contingent transactions (linked to a fact) as actual trading. On the other hand, incorrect valuation in the context of fraudulent reporting options is mainly related to erroneous estimates in the form of provisions. Provisions thus give us room to reduce or increase (in the case of non-settlement) the company's financial results based on the estimate of the company's management (Kral et al., 2019)

Unrecognized liabilities or costs, where disclosing unrecognized liabilities can sometimes be very challenging. In checking such commitments, we may use, for example, confirmations from the company's suppliers (Ayu et al., 2020). However, we can also include among the unrecognized liabilities the commonly neglected creation of reserves, for example for warranty repairs or bonuses for employees. (Haskins et al., 2020) Uncommitted commitments may also take the form of erroneous annexes. This is because some companies may have a large number of dispositions. At present, there are generally two main reasons for manipulating financial statements, either an increase in profit or loss due to an improvement in the market position or a decrease in profit or loss due to tax optimization (Kliestikova et al., 2017)

\section{Research Methods}

In a modern globalized and liberalized era, companies face stiff competition and are therefore under constant pressure. Mainly to demonstrate good financial results through their financial reporting system. In such an environment, businesses typically use creative accounting practices. There are many economic facts that are considered as reasons for applying creative accounting techniques.

The aim of the presented article is to analyse the possibilities of using the chosen technique and method of profit manipulation on the selected company. The selected company operates in the Slovak market. Another partial goal will be the evaluation of selected techniques. The selected company is the company that "optimized" its financial statements for tax purposes and was officially convicted of financial fraud in 2018. The selected company was obliged to pay an additional tax and fine. The selected company was analysed for the period from 2016 to 2020. The data were used from the financial 
statements, balance sheet and profit and loss statements. These data were submitted to the state authority of the Slovak Republic as regular financial statements. The selected company has a legal form as a limited liability company, where according to Slovak accounting standards and the legislation of the Slovak Republic, it is obliged to keep double-entry bookkeeping. In terms of classification, the selected company is included in the category of a medium-sized enterprise.

\subsection{Selected fraudulent techniques}

At present, however, there are various complicated statistical methods or techniques of data collection that can identify hidden, unusual or divergent patterns indicating fraud. These are various analytical models used to detect possible errors and fraud in accounting. In the presented article we will focus on two models, namely the Beniesh model and the Kanapickiene - Grundiene model. In practice, it is assumed that these models are able to detect inconsistencies within the company. The common feature of the selected models is that none of them was developed and adapted to the conditions of the Slovak Republic. For these reasons, they are not even in accordance with Slovak accounting regulations and standards. The Beneish model works on the basis of GAAP, where the KG model on the Lithuanian accounting and reporting standards. Based on this, we have approximated certain input data in accordance with the content of financial indicators in the source research articles. Therefore, in the presented article we did not only examine the final scores but also the development of individual financial indicators.

\subsubsection{Beniesh model}

It is a mathematical-statistical model containing eight variables, which can be used to identify possible data manipulation based on financial statements (Tarjo \& Herawati, 2015). The main definitional relationship is based on equation (1), where the abbreviations of financial indicators and their calculations are given in Table 01 .

$$
\begin{gathered}
\mathrm{M}=-4.84+0.920 * \mathrm{DSRI}+0.528 * \mathrm{GMI}+0.404 * \mathrm{AQI}+0.892 * \mathrm{SGI}+0.115 * \mathrm{DEPI}-0,172 * \\
\mathrm{SGAI}+4.679 \mathrm{TATA}-0.327 \mathrm{LVGI}
\end{gathered}
$$

\begin{tabular}{|c|c|}
\hline Indicator & Characteristics \\
\hline DSRI & Days sales in Receivables Index $=\left(\right.$ Receivables $_{1} /$ Sales $\left._{1}\right) /({\text { Receivablest- } 1 / \text { Salest }-1)}$ \\
\hline GMI & $\begin{array}{c}\text { Gross Margin Index }=\left[\left(\text { Sales } t-1-\text { Costs of goods sold }_{t-1}\right) / \text { Sales }_{t-1}\right] /[(\text { Salest }- \text { Costs of goods } \\
\left.\left.\text { sold }_{t}\right) / \text { Salest }_{t}\right]\end{array}$ \\
\hline AQI & $\begin{array}{c}\text { Asset Quality Index }=[1-(\text { Current assets } t+\text { Property, plant, equipmentst }) / \text { Assets } t] /[1-(\text { Current assetst-1 }+ \\
\text { Property, plant, equipmentst-1)/Assetst-1] }\end{array}$ \\
\hline SGI & Sales Growth Index $=$ Salest $/$ Salest-1 \\
\hline DEPI & $\begin{array}{c}\text { Depreciotion Index }=\left[\text { Deperciation }_{\mathrm{t}-1}+\text { net Property, plant, equipmentst-1)]}\right] \\
{\left[\text { Depreciation }_{\mathrm{t}} /\left(\text { Depreciotion }_{\mathrm{t}}+\text { net Property, plant, equipmentst }\right)\right]}\end{array}$ \\
\hline SGAI & $\begin{array}{l}\text { Sales General and Administrative Expenses Index }=(\text { Selling, general, administrative } \\
\left.\text { expense }_{t} / \text { Sales }_{t}\right) /\left(\text { Salling, general, administrative expense } t_{-1} / \text { Salest }-1\right)\end{array}$ \\
\hline LVGI & $\begin{array}{c}\text { Leverage Index }=\left[\left(\text { Long term debt }_{t}+\text { Current liabilities }_{\mathrm{t}}\right) / \text { Assets }_{\mathrm{t}}\right] /\left[\left(\text { Long term debt }_{\mathrm{t}-1}+\text { current }\right.\right. \\
\text { liabilitiest }-1) / \text { Assetst }-1]\end{array}$ \\
\hline TATA & 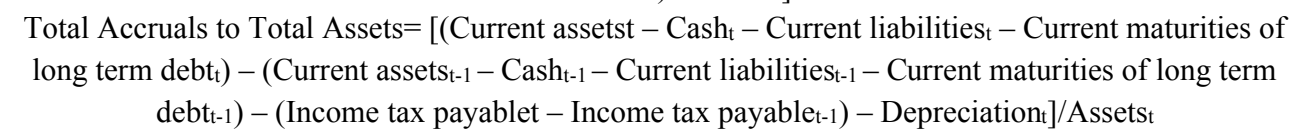 \\
\hline
\end{tabular}

Table 1. Beneish model characteristics

Source: own processing according to Tarjo and Herawati (2015). 
The Beneish model assumes that companies are motivated to manipulate profits if they have high sales growth, deteriorating gross margins, rising operating costs and growth in leverage. Beneish concluded that if the company achieved a higher score than -2.22 , i.e. a less negative or positive number, then there is a probable likelihood of manipulation of profits (Ahmet, 2018).

\subsubsection{Kanapickiene - Grundiene model}

It is a model that also detects fraudulent financial indicators, but this model works on the basis of logistic regression. The original model contained 32 financial indicators, while the final model of logistic regression contains 4. The main definition relationship is based on equations (2) and (3), where the abbreviations of financial indicators and their calculations are given in Table 02 .

$$
\begin{aligned}
& \mathrm{P}=1 /\left(1+\mathrm{e}^{\mathrm{KG}}\right) \\
& \mathrm{KG}=5.768-4.236 * \mathrm{ASR}-0.029 * \mathrm{AR}-4.766 * \mathrm{SR}-1.936 * \mathrm{LR}
\end{aligned}
$$

Table 2. Kanapickiene - Grundiene model characteristics

\begin{tabular}{cc}
\hline Indicator & Characteristics \\
\hline ASR & Assets Structure Ratio $=$ Inventories/Assets \\
AR & Activity Ratio $=$ Sales/Fixed Assets \\
SR & Solvency Ratio $=$ Liabilities/Assets \\
LR & Liquidity Ratio $=$ Cash $/$ Current liabilities \\
\hline
\end{tabular}

Source: own processing according to Tarjo \& Herawati, 2015.

The overall capability of the Kanapickiene - Grundiene model is $84.8 \%$ of correctly identified companies that manipulated profits. $\mathrm{P}$ is the probability of fraud in financial statements (from 0 to 1 ). When $\mathrm{P}>50 \%$, financial statements are fraudulent; when $\mathrm{P}<50 \%$, financial statements are non-fraudulent (Kanapickiene \& Grundiene, 2015).

\section{Results and Discussion}

In the analysed period 2016 - 2020, the economic result of the selected company had a negative value in all years, except for 2015 and 2020. The lowest value of EAT was recorded by the company in 2018. The sales of the selected company also fluctuated. The highest sales were achieved in 2016 and the lowest in 2018.

In the presented article, as we have already mentioned above, we will focus on two models, namely the Beneish model and the Kanapickiene - Grundiene model. The aim of the presented article is to analyse the possibilities of using the chosen technique and method of profit manipulation on a selected company. The results can be seen in table 03, which shows the individual financial indicators of the selected models, values and the resulting score for each year. 
Table 3. Results of analysed models

\begin{tabular}{|c|c|c|c|c|c|c|}
\hline $\begin{array}{c}\text { BENISH MODEL } \\
\text { (M) }\end{array}$ & $\begin{array}{l}\text { Weight of } \\
\text { Indicator }\end{array}$ & $2015 / 2016$ & 2016/2017 & $2017 / 2018$ & 2018/2019 & $2019 / 2020$ \\
\hline (DSRI) & 0,920 & 0,0000 & 0,7623 & 0,8553 & 1,2770 & 0,8570 \\
\hline (GMI) & 0,528 & 1,0356 & 0,7049 & 0,8207 & 0,7962 & 0,9427 \\
\hline (AQI) & 0,404 & 0,8394 & 1,3726 & 0,9887 & 0,7071 & 0,2979 \\
\hline (SGI) & 0,892 & 1,4542 & 0,7263 & 0,8553 & 1,2770 & 0,8570 \\
\hline (DEPI) & 0,115 & 0,5984 & 0,6905 & 0,5865 & 1,0903 & 0,7997 \\
\hline (SGAI) & 0,172 & 1,0408 & 1,2817 & 0,9891 & 0,8173 & 1,0611 \\
\hline (LVGI) & 0,327 & 1,8393 & 4,1549 & 4,2392 & 1,8518 & 1,4349 \\
\hline (TATA) & 4,697 & $-0,0666$ & $-1,5797$ & $-2,8203$ & 0,0745 & $-3,1953$ \\
\hline Intercept $-4,840$ & M-score & $-3,6816$ & $-11,4836$ & $-17,1931$ & $-2,0910$ & $-18,2369$ \\
\hline KG MODEL (KG) & $\begin{array}{l}\text { Weight of } \\
\text { Indicator }\end{array}$ & 2016 & 2017 & 2018 & 2019 & 2020 \\
\hline (ASR) & 4,263 & 0,3262 & 0,0752 & 0,0857 & 0,3534 & 0,8074 \\
\hline (AR) & 0,029 & 2,5827 & 3,1145 & 5,0983 & 15,1090 & 44,9279 \\
\hline (SR) & 4,766 & 0,7366 & 1,7278 & 4,8271 & 6,8187 & 8,0053 \\
\hline (LR) & 1,936 & 2,9984 & 0,1368 & 0,0338 & 0,0815 & 0,1292 \\
\hline Intercept 5,768 & $\mathrm{P}(\%)$ & 0,3225 & 0,3205 & 0,3363 & 0,3493 & 0,3600 \\
\hline
\end{tabular}

Source: own processing

Based on the performed analysis, we can see that we can classify the analysed company among the companies that manipulated the profit. However, this statement can only be made on the basis of the Beneish model. As we can see, the values of individual indicators are relatively unstable and have a fluctuating character. In 2016, the M-score reaches only - 3.6816 and in 2020 to -18.2369 , which is a significant difference. In 2018, the Beneish model revealed possible manipulation of profits, which was confirmed to us as the company was officially convicted of financial fraud in 2018.

If we look at the results of the Kanapickiene - Grundiene model, he did not prove to us that the company was a manipulator at all. In the analysed period, none of the values approached the P-value, whose limit value is $50 \%$. We assume that this happened due to the high value of liquidity and activity. From the development of these financial indicators, it can be said that the ratio fluctuated the most from the group of all indicators in this model.

One way to prevent the manipulation of financial statements is to adopt a new and more efficient accounting program. Another way to detect creative accounting is to perform an internal audit. The main reason is that it is better to control your own business transactions before the Office of Audit or the Ministry of Finance (Liem \& Hien, 2020). It is a cross, internal control. In practice, this is simply used when the company hires another accountant to help the chief accountant. In these cases, the assistant accounting officer may see errors which the chief accounting officer does not see. This can help the business reduce its ability to manipulate profits. Completion of ethical courses can be included as another way to reduce the manipulation of profits (Svabova et al., 2020) It would be appropriate for companies to include in these courses anyone who deals with the company's finances, from the acting CFO to the invoice. Another very important way is to manage some key factors (corporate governance) to reduce creative accounting risks. This is continuous information with financial statements and ongoing analysis of the financial situation in the company (Grofcikova, 2020). 


\section{Conclusion}

The aim of the presented article was to analyse the possibilities of using the chosen technique and method of profit manipulation on a selected company in the conditions of the Slovak Republic and to evaluate the consequences of selected models. However, the results of the present article show us that only the Beneish model identified the company as fraudulent exactly in the year when the company was officially recognized as having committed financial fraud. The Kanapickiene - Grundiene model was not described by the company as a clear manipulator. An important fact, however, is that the selected models were not developed, developed and adapted to the conditions of the Slovak Republic. Based on these facts, it is necessary to regularly perform deeper and more comprehensive research of any fraudulent technique and apply them in the conditions of the Slovak Republic.

Creative accounting and the risks associated with it offer an impressive challenge to the accounting profession, which, in an extremely negative way, has penetrated the credibility of accounting standards and principles. In general, creative accounting is used for deceptive and undesirable practices. Although there are accounting standards such as IFRS and IAS for the management of financial accounting activities, it is sometimes impossible to avoid the manipulative behaviour of preparable financial statements. These compilers want to use these financial statements to influence the decisions of users of financial statements in favour of their business. The complexity and unpredictability of an everchanging environment make it difficult to set standards in all possible situations. Although accounting standards cannot prevent manipulative behaviour in advance, they may limit it later.

\section{Acknowledgments}

The paper is an output of the science project VEGA 1/0210/19 Research of innovative attributes of quantitative and qualitative fundaments of the opportunistic earnings modelling which authors gratefully acknowledge.

\section{References}

Ahmet, O. (2018). The use of Beneish model in forensic accounting: evidence from Turkey. Journal of Applied Economics and Business Research, 8(1), 57-67.

Ayu, M., Gamayuni, R. R., \& Urbanski, M. (2020). The impact of environmental and social costs disclosure on financial performance mediating by earning management. Polish Journal of Management Studies, 21(1), 74-86. https://doi.org/10.17512/pjms.2020.21.2.06

Grofcikova, J. (2020). Impact of selected determinants of corporate governance on financial performance of companies. Ekonomicko-manazerske spektrum, 14-23. https://doi.org/10.26552/ems.2020.2.12-23

Haskins, P., Luțan (Petre), A. G., \& Tanase, A. (2020). Sustainable Value Creation Networks, Digitized Mass Production, and Networked Information-driven Technologies in Industry 4.0-based Manufacturing Systems. Economics Management and Financial Markets, 15(2), 37-43. https://doi.org/10.22381/EMFM15220205

Howard, F., Kral, P., Janoskova, K., \& Suler, P. (2020). Risk Perception and Societal Acceptance of Autonomous Vehicle Technologies. Contemporary Readings in Law and Social Justice, 12(1), 4450. https://doi.org/10.22381/CRLSJ12120206 
Kanapickiene, R., \& Grundiene, Z. (2015). The model of fraud detection in financial statementsby means of financial ratios. Procedia - Social and Behavioral Sciences, 213, 321-327. https://doi.org/10.1016/j.sbspro.2015.11.545

Kliestikova, J., Misankova, M., \& Kliestik, T. (2017). Bankruptcy in Slovakia: international comparison of the creditor's position. Oeconomia Copernicana, 8(2), 221-237. https://doi.org/10.24136/oc.v8i2.14

Kral, P., Valjaskova, V., \& Janoskova, K. (2019). Quantitative approach to project portfolio management: proposal for Slovak companies. Oeconomia Copernicana, 10(4), 797-814. https://doi.org/10.24136/oc.2019.036

Liem, V. T., \& Hien, N. N. (2020). The impact of manager's demographic characteristics on prospector strategy, use of management accounting systems and financial performance. Journal of International Studies, 13(4), 54-69. https://doi.org/10.14254/2071-8330.2020/13-4/4

Pieters, M. (2019). International Code of Ethics for Professional Accountants: A Behind the Scenes Look at the eCode. Australian Accounting Review, 29(3), 595-598. https://doi.org/10.1111/auar.12295

Salaga, J., Bartosova, V., \& Kicova, E. (2015). Economic Value Added as a measurement tool of financial performance. Procedia Economics and Finance, 26(9), 484-489. https://doi.org/10.1016/S2212-5671(15)00877-1

Savova, K. (2021). Variable application of accounting standards - current aspects. Ekonomickomanazerske spektrum, 15(1), 111-122. https://doi.org/10.26552/ems.2021.1.111-123

Siekelova, A., Kollar, B., \& Weissová, I. (2015). Impact of credit risk management. Procedia Economics and Finance, 26, 325-331. https://doi.org/10.1016/S2212-5671(15)00860-6

Stangova, N., \& Vighova, A. (2016). Possibilities of creative accounting avoidance in the Slovak Republic. Economic Annalis-XXI, 158(3-4), 97-100. https://doi.org/10.21003/ea.V158-22

Svabova, L., Kramarova, K., Chutka, J., \& Strakova, L. (2020). Detecting earnings manipulation and fraudulent financial reporting in Slovakia. Oeconomia Copernicana, 11(3), 485-508. https://doi.org/10.24136/oc.2020.020

Tarjo \& Herawati, N. (2015). Application of Beneish M-Score model and data mining to detect financial fraud. Procedia - Social and Behavioural Sciences, 211, 924-930. https://doi.org/10.1016/j.sbspro.2015.11.122

Vagner, L., Valaskova, K., Durana, P., \& Lazaroiu, G. (2021). Earnings management: A bibliometric analysis. Economics and Sociology, 14(1), 249-262. https://doi.org/10.14254/2071-789X.2021/14$1 / 16$

Wells, J. T. (2014). Principles of Fraud Examination (4 ed.). Wiley. 